\title{
ECOLOGY
}

\section{POSSIBILITIES OF PURIFICATION OF HEAVY METALS CONTAMINATION IN SOILS}

\author{
Ph.D, Candidate of chemical sciences N. A. Kavtaradze, \\ Ph.D, Candidate of chemical sciences K. N. Kochiashvili, \\ Ph.D, Candidate of chemical sciences M. A. Stephanishvili, \\ Scientist T. A. Dgebuadze, \\ Scientist M. Z. Japaridze \\ Georgia, Tbilisi, Iv. Javakhishvili Tbilisi State University, \\ P. Melikishvili Institute of Physical and Organic Chemistry
}

DOI: https://doi.org/10.31435/rsglobal_wos/30112019/6801

\section{ARTICLE INFO}

Received: 13 September 2019

Accepted: 12 November 2019

Published: 30 November 2019

\section{KEYWORDS}

heavy metals, radionuclide, contamination, neutralization, remediation.

\begin{abstract}
Methods of neutralisation of different types of soils contaminated with heavy metals are studied. Certain strains of microorganisms have been selected, local microflora has been studied and identified at the genus level in laboratory conditions. Considering the conducted works, development of modified forms of humic acids, stimulation of local microorganisms and creation of geochemical barriers using local natural raw materials is recomended. Obtained results makes possible to develop comprehensive and rational model by means of inovative technologies for effective purification of soils contaminated with heavy metals.
\end{abstract}

Citation: N. A. Kavtaradze, K. N. Kochiashvili, M. A. Stephanishvili, T. A. Dgebuadze, M. Z. Japaridze. (2019) Possibilities of Purification of Heavy Metals Contamination in Soils. International Academy Journal Web of Scholar. 11(41), Vol.1. doi: 10.31435/rsglobal_wos/30112019/6801

Copyright: (C) 2019 N. A. Kavtaradze, K. N. Kochiashvili, M. A. Stephanishvili, T. A. Dgebuadze, M. Z. Japaridze. This is an open-access article distributed under the terms of the Creative Commons Attribution License (CC BY). The use, distribution or reproduction in other forums is permitted, provided the original author(s) or licensor are credited and that the original publication in this journal is cited, in accordance with accepted academic practice. No use, distribution or reproduction is permitted which does not comply with these terms.

Introduction. One of the main problems of our time is the study of sources of environmental pollution, protection and purification of envirnment with effective methods from pollutants of various origin (type) and species. One of the sources of pollution of natural ecosystems are byproducts, containing a certain amount of different pollutants and produced by the work of different sectors of the industry. The type of pollutants is diverse and changes with the implematation of new technologies.

It should be noted, that there are several sources of heavy metal contamination in Georgia. The following metals belong to the main pollutants: arsenic, copper, lead, cadmium, strontium, strontium, nickel, chrome and others. Radionuclide pollution is observed in the Black Sea regions of Georgia. The map of pollution with heavy metals of the territory of Georgia is drawn up, the level of contamination and polluted places are identified. The most contaminated places with radionuclides are identified (the southern part of Georgian Black Sea Coast of Adjara and Ozurgeti regions). It is necessary to determine the initial data of heavy metals concentration using modern technologies [1].

Two forms of environmental pollution with radionuclides are distinguished: natural and artificial. The sources of natural polution are natural cataclysms and are caused by natural radioactive isotopes that always present in a certain amount in environment (soil, water). Natural radioactive elements are mostly evenly distributed in soils and are found in strongly bonded forms. Sources of artificial pollution with radioactive isotopes are industrial production, radionuclides generated by various atomic and thermonuclear explosions. 
The results of artificial contamination of soils with radioactive compounds are severe, radionuclides through the vegetable and animal food are entering and the life cycle of humans and animals causing a real threat to the environment and to human.

Especially dangerous are the ${ }^{137} \mathrm{Cs}$ and ${ }^{90} \mathrm{Sr}$, which is caused by their half-life speed (30.2 and 28.7 years respectively), high radiation energy and high ability to be engaged in the the food chain. They are found more often in human food as they are easily absorbed by plants, and are causing a real threat to humans. Chemical properties of strontium are similar to calcium and absorbed strontium mainly is accumulated in bones. Cesium has similar properties to potassium, which is involved in many processes of living organisms.

Artificial radionuclides mainly accumulate in the soil upper layers (80-90\%). This depends on various factors and varies with the mechanical and mineral composition, as well as the acidity of the soil. The soils with high humus content and heavy granulometric composition, as well as dry soils rich with montmorolite clays are distinguished by their ability to accumulate radionuclides. Migration of radionuclides in such soils is limited.

The rate of purification of soils from radionuclides is determined by the rate of radioactive decay, and rvertical and horizontal migration. It should be noted that during radioactive contamination of the soil surface the amount of radioactive ions is very small and does not change the basic properties of the soil: $\mathrm{pH}$, coexistence of mineral nutrients, soil fertility

Chemical and microbiological technologies belong to the modern methods for the purification of soils from radionuclides. For this purpose, some bacteria and fungi are selected that accumulate heavy metals, phytoremediation is also possible. For implementation of these methods, quantity of radionuclides in soils must be determined, as well as type of soilb, acidity and others should be defined.

Many microorganisms are resistant to the toxic effects of heavy metals. The resistance of microbial cultures can be gradually increased by culturing them in an environment of increasing concentrations of heavy metals. disposal of heavy metals takes place by bonding, chelating, precipitating and transforming them into less toxic forms by changing their valence or by forming metal organic compounds. [2-6].

For binding heavy metals can be used representatives of different taxonomic groups: sulfatereducing microorganisms, cyanobacteria, purple bacteria, iron - and nitrogen-fixing bacteria. Some strains of bacteria can reduce water-soluble sulfates to water insoluble sulfides. During the life activity of these bacteria, cadmium, lead, and copper sulfides are released into the soil and enter groundwater [7].

Research results. Optimal conditions for biostimulation of selected local microscopic fungi for xenobiotics accumulation are working out. Correction of soils acidity with a slake lime is planned, that will prolong soil fertility in the presence of calcium. Plant substrates are used for microscopic fungi development. Remediation methods of soils contaminated with heavy metals are being developed.

Use of modified natural sorbents for absorption and fixation of heavy metals is possible, that will help to protect the environment from uncontrolled migration of heavy metals using geochemical barriers. As a components of geochemical barriers, clay minerals kaolinite and montmorillonite are mainly used [8]. It is known that particles of fatty clays promote the precipitation of xenobiotics and prevent the transfer of contamination to groundwater. For obtaining modified natural sorbets, that will have higher ability of radionuclides sorption, organic components as well as inorganic are used. For treatment of clays, as an organic components the derivates of humic acids isolated from pitch will be used, and for increasing the sorption capacity inorganic acids and their salts will be used.

It should be noted that in situ purification of soils contaminated with heavy metals by biotechnological methods using microorganisms is difficult because the free movement of bacterial cells in soils is limited. Therefore, the use of surfactans produced by biosurfactants presents a potential alternative for purification of contaminated soils. Research on the mobilisation and isolation of heavy metals by Rhodococcus biosurfactants complexes is underway. The use of Rhodococcus biosurfactants is more favorable than of synthetic surfactants as it is environmentally safe and has high functional activity. Rhodococcus promote the movement of heavy metals in soils and their bioavailability to soil microorganisms [9-10].

At the first stage of the experiment, certain strains of microorganisms have been selected. For the purpose of bioremediation, local microorganisms isolated from samples taken from extreme environments are studied: thermal sources, drains of iron and sulfur rocks, rocky breeds, etc.These microorganisms were identified in the laboratory at genus level (Table. N1). 
Table 1. Microorganisms isolated from extreme environments and identified at genus level

\begin{tabular}{|l|l|l|l|l|}
\hline Cyanobacteria & Ironbacteria & Sulfur bacteria & Purple Bacteria & $\begin{array}{l}\text { Nitrogen-fixing } \\
\text { bacteria }\end{array}$ \\
\hline Anabaena & Leptothrix & Chromatiaceae & $\begin{array}{l}\text { Rhodococcus } \\
\text { bacteria }\end{array}$ & Azotobacter \\
\hline Nostoc & Ferribacterium & Thiodictium & Neiseria & Rhyzobium \\
\hline Shyzzophyta & Galionela & Desulfovibrio & Legionela & Nitrobacter \\
\hline
\end{tabular}

The acidity of soil samples artificially contaminated with various metals $\left(\mathrm{Pb}^{+2}, \mathrm{Cr}^{+2}, \mathrm{Cd}^{+2}\right.$, $\left.\mathrm{Sr}^{+2}, \mathrm{Ni}^{+2}, \mathrm{Cu}^{+2}\right)$ have also been determined. Soils of the same mass $(200 \mathrm{~g})$ have been taken to form model samples. Each sample was contaminated with aqueous solutions of soluble heavy metal salts $(0.1 \mathrm{~N})$. Soil sample uncontaminated with heavy metals is taken as a control.

After implementation of the first phase works, it is advisable to continue research on the development of an integrated and rational model of the purification of soils contaminated with heavy metals.

\section{REFERENCES}

1. Urushadze T. F, Manakhov D. V. Radioactive contamination of the soils of Georgia. Annals of Agrarian Science. 2017; 15: 375-379.

2. Dolidze A., Mikadze I., Chkhaidze K., Kavtaradze N., Dolidze L., Barbakadze N., Uridia R. Possibilities of reducing of ecological danger of polluted sites by radionuclides, precipitated from atmosphere. Transactions of Petre Melikishvili Institute of Physical and Organic Chemistry, Tbilisi, 2011: 81-83

3. Castro L, Blázquez M, González F, Muñoz J, Ballester A. Heavy metal adsorption using biogenic iron compounds. Hydrometallurgy. 2018; 179: 44-51.

4. Yadav S.K. Heavy metals toxicity in plants: An overview on the role of glutathione and phytochelatins in heavy metal stress tolerance of plants. South African Journal of Botany. 2010; 76: 167-179.

5. Ившина И. Б, Куюкина М. С, Костина Л.В, Тищенко А. В. Извлечение тяжелых металлов из техногенно загрязненных городских почв. Аграгный вестник Урала. 2014. 11(129).

6. Савич В.И, Белоухов С.Л, Никиточкин Д.Н, Филлипова А.В. Новые методы очистки почв от тяжелых металлов. 2013. 4 (42): 216-218.

7. Nzihou A, Sharrock P. Role of Phosphate in the Remediation and Reuse of Heavy Metal PollutedWastes and Sites. Waste Biomass Valor (2010) 1:163-174

8. Rafael Celis R, M. Carmen HermosínM. C, Cornejo J. Heavy Metal Adsorption by Functionalized Clays. Environ. Sci. Technol. 2000, 34, 21:4593-4599.

9. Christofi N, Ivshina I.B. Microbial surfactants and their use in field studies of soil remediation. J. Appl. Microbiol. 2002, 93: 915-929.

10. Kostina L. V, Kuyukina M. S, Ivshina I. B. Evaluation of Rhodococcus biosurfactant potential towards the remediation of heavy metals from contaminated soils of Sverdlovsk region. Вестник Пермского Университета. 2014. 4:73-77. 